\title{
The Danish Reformation Celebrations as Civil Religion
}

Warburg, Margit

Published in:

Journal of Church and State

DOI:

$10.1093 / \mathrm{jcs} / \mathrm{csy} 030$

Publication date:

2019

Document version

Publisher's PDF, also known as Version of record

Citation for published version (APA):

Warburg, M. (2019). The Danish Reformation Celebrations as Civil Religion. Journal of Church and State, 61(2), 222-241. [3]. https://doi.org/10.1093/jcs/csy030 


\title{
The Danish Reformation Celebrations as Civil Religion
}

\author{
Margit Warburg
}

In 2017 , the $500^{\text {th }}$ anniversary of the onset of the Lutheran Reformation was celebrated in several European countries - first and most, of course, in the countries of the traditional Lutheran heartland: Germany, Denmark, Norway and Sweden. ${ }^{1}$

It is hardly surprising that the Lutheran churches of these four countries were celebrating the events that led to their birth as breakaway churches from the Roman Catholic Church. However, when looking closer at the explicit motives for the celebrations and the degree of state involvement, there are distinct differences between the four countries. In Norway and Sweden, the celebration of the Reformation jubilee was arranged by the Norwegian and Swedish churches, and the emphasis was on the confessional significance of the Lutheran Reformation. ${ }^{2}$ For example, the main

MARGIT WARBURG (MA and DPhil, University of Copenhagen) is professor in sociology of religion, University of Copenhagen. She is author of Citizens of the World. A History and Sociology of the Baha'is from a Globalisation Perspective (2006) and "Secular Rituals" in Research Companion to Anthropology (2015). Her major recent publication "Much Ado about a Christmas Tree: A Conflict Involving Danish Civil Religion" appeared in Implicit Religion (2017). Her articles have also appeared in Journal of Ritual Studies, Nordic Journal of Religion and Society, Social Compass, and Journal of Contemporary Religion. Special interests include Danish churches abroad, Baha'i, and religion and globalization.

1. The largely Lutheran countries Finland, Estonia and Latvia, which belonged to the Swedish empire in the 1500s and 1600s (Finland until 1809), marked the $100^{\text {th }}$ anniversary for their independance from Czarist Russia in 2017. The celebration of the Reformation coinicided with these national markings and the Reformation was therefore not the foremost event. The Lutheran Iceland, which was ruled by Denmark until 1944, also did not turn the Reformation anniversary into a big national event; this may perhaps be rooted in history because the Reformation was forced upon the Icelandic people by the Danish king in 1550 after a Danish army had crushed a rebellion led by the last Catholic bishop of Iceland, Jón Arason.

2. www.kirken.no/nb-NO/reformasjon-2017; www.svenskakyrkan.se/church-ofswedens-focus-on-reformation-year-2017.

Journal of Church and State vol. 61 no. 2, pages 222-241; doi:10.1093/jcs/csy030 Advance Access Publication April 20, 2018

(C) The Author(s) 2018. Published by Oxford University Press on behalf of the J. M. Dawson Institute of Church-State Studies. All rights reserved. For permissions, please e-mail: journals.permissions@oup.com 
theme of the Norwegian Church was nåde (grace) which was expounded in three sub-themes: Frelsen er ikke til salgs (God's salvation is not for sale), Mennesker er ikke til salgs (human beings are not for sale), and Skaperverket er ikke til salgs (God's creation is not for sale). The choice of these sub-themes is a token of the political activism of the Norwegian Church after its bonds with the state were loosened in 2008 to become fully effective by $2017 .^{3}$

In Germany, where there is no national church, the federal government supported the celebration, stressing that it achieved its goal of being ecumenical and international in its scope. ${ }^{4}$ This emphasis is different from former jubilees, in particular from the 400-year jubilee in 1917, which was celebrated during the First World War. ${ }^{5}$ Martin Luther was then used in the war propaganda as a German hero figure, "Der deutscheste Mann, den es je gegeben hat" (the most German man ever). ${ }^{6}$

In contrast to the situation in the above three countries, the Reformation celebration in Denmark distinguished itself by its official emphasis on the national significance of the Reformation in Denmark. This appears from the mandate of the governmentappointed presidium overseeing the celebrations:

The Presidium of the $500^{\text {th }}$ Reformation Anniversary in Denmark has overall responsibility for the celebration of the anniversary with the goal of increasing understanding of the impact of the Reformation on society, the church, identity and consciousness in Denmark. ${ }^{7}$

The differences in the official perception of Luther and the Reformation between the countries reflect, among other things, that the heritage from the Reformation is, indeed, a flexible resource.

3. An example of this activism is that in 2013, the general assembly of the church (Kirkemøtet) approved a declaration about what the church called an ethical, responsible management of the big Norwegian, state-owned fund (Oljefonden) generated by the huge accumulated earnings from the Norwegian oil fields in the North Sea (Den Norske Kirke, Kirkemøtet i Kristiansand 11-16 April 2013, doc. no. 93485: Forsvarlig etisk forvaltning av norske petroleumsressurser og bruk av oljefondet - forslag til uttalelse).

4. www.reformationsjubilaeum-bund.de - see link to Bilanz der Bundesregierung.

5. www.deutschlandfunk.de/luther-1917-und-2017-der-deutscheste-mann-denes-je-gegeben.886.de.html?dram:article_id=379679.

6. Martin Kronenberg, Kampf der Schule an der "Heimatfront" im Ersten Weltkrieg: Nagelungen, Hilfsdienste, Sammlungen und Feiern im Deutschen Reich [Fight of the school on the "home front" in the First World War: nailings, auxiliary services, collections, and celebrations in the German Reich] (Hamburg: Disserta Verlag, 2014), 223-25.

7. http://en.luther2017.dk/the-presidium/. 
The Danish church historian, Carsten Bach-Nielsen has noted that the different historical Danish Reformation jubilees have had the common theme of thanksgiving to God for religious enlightenment and liberation of the king's realm and subjects from the papal church. ${ }^{8}$ However, when I began to study the Danish Reformation jubilees, I also noted that the national significance of the Reformation and a special relationship between Denmark and God was a recurrent theme in the celebrations, right from the first one in 1617 to the latest in 2017. I interpret this as an expression of a Danish civil religion. This civil religion is rooted in the historical development of the Evangelical Lutheran Church in Denmark and has gained its characteristics from a particular Danish relation between nation, church, and state. The interpretation of the Danish Reformation celebrations as an example of civil religion is based on an analysis of the historical Reformation jubilees in Denmark and in particular on fresh empirical material from the Danish Reformation jubilee in 2017.

A note on the term "Denmark" is warranted to avoid confusion. Through most of history, the Danish kings have ruled nations other than Denmark, first and foremost Norway, Iceland, and the North German duchies Schleswig and Holstein. Greenland and the Faroe Islands are still part of the Kingdom of Denmark. In the present work, "Denmark" and "Danish" relates exclusively to Denmark proper.

\section{Civil Religion in Brief}

The concept of civil religion is important for many studies of religion and society, and the literature on the subject is extensive. ${ }^{9}$ The following is a very condensed exposition of those central aspects of civil religion, which are relevant in the analyses of the Reformation celebrations.

In brief, civil religion is a conglomerate of myths, rituals, symbols, and texts, which hallow the people or the nation by reference to a superhuman power, usually called God. ${ }^{10}$ By such a reference

8. Carsten Bach-Nielsen, Fra jubelfest til kulturår. Danske reformationsfejringer gennem 400 år [From jubilation to cultural year. Danish Reformation celebrations through 400 years] (Aarhus: Aarhus Universitetsforlag, 2015), 339-43.

9. For a general review, see Marcela Cristi and Lorne L. Dawson, "Civil Religion in America and in Global Context," in The Sage Handbook of the Sociology of Religion, ed. James A. Beckford and N.J. Demerath III (Los Angeles: Sage 2007), 267-92.

10. Phillip E. Hammond, "The Sociology of American Civil Religion: A Bibliographical Essay," Sociological Analysis 37 (1976): 169-82; Cristi and Dawson, "Civil Religion in America and in Global Context"; Margit Warburg, "Dannebrog: Waving in and out of Danish Civil Religion," Nordic Journal of Religion and Society 21 (2008): 165-83. 
to an unquestionable authority, rulers have often legitimized the particular social order of a country. When philosopher JeanJacques Rousseau proposed the establishment of a civil religion in 1762, this top-down use of civil religion was salient in his writings. ${ }^{11}$

Robert N. Bellah reinvigorated the concept of civil religion in an American setting in 1967 to explain why Americans of all creeds seemed to accept that the presidents in their speeches consistently claimed a special religious legitimacy of the American nation and the American constitution. ${ }^{12}$ Bellah referred to Rousseau, of course, but he also argued for considering American civil religion a Durkheimian religious dimension of society in concord with popular sentiments about the characteristics and destiny of the United States. ${ }^{13}$ The Durkheimian dimension represents an interpretation of civil religion as sustained by bottom-up processes in civil society.

Both top-down and bottom-up processes are at play in many examples of civil religion. The two expressions of civil religion are not each other's opposites but should be seen as complementary ideal types. ${ }^{14}$ Typically, when the nation is officially celebrated and civil religion is involved, there is a combination of top-down and bottom-up processes, and both are likely to be present for a successful completion. Organization from above is often administratively and economically necessary, while participation from below gives the manifestation of civil religion popular legitimacy. This is also clearly seen in the Danish celebrations of Reformation anniversaries throughout history and not the least at the celebrations in 2017.

\section{The Historical Reformation Jubilees}

The Reformation in Denmark was rather early and swift; but it was also a politically complicated process that involved power struggles between king, nobility and the bourgeoisie, peasant uprisings in Jutland, and a civil war with interference from the

11. Victor Gourevitch, ed., trans., Rousseau. The Social Contract and other later political writings (Cambridge: Cambridge University Press, 1997), 142-51.

12. Robert N. Bellah, "Civil Religion in America," Doedalus 96 (1967): 1-21. This characteristic aspect of American civil religion was later analysed in depth by Richard V. Pierard and Robert D. Linder, Civil Religion and the Presidency (Grand Rapids: Zondervan, 1988).

13. Bellah, "Civil Religion in America."

14. Warburg, "Dannebrog: Waving in and out of Danish Civil Religion." 
outside. ${ }^{15}$ Already during the 1520 s, Luther's reform ideas had become widely popular among the citizens in Denmark, and in several cities Lutheran church services were regularly conducted in the churches. ${ }^{16}$ This development was encouraged by the Danish King Frederick I (reigned 1523-1533), who thereby opposed the Catholic majority in the Council of the Realm (Rigsrådet). The final process towards the ultimate break with the papal church was ruthlessly carried through by Frederick I's successor, Christian III (reigned 1534-1559), who had become a convinced follower of Luther already as a young prince. When he was elected king in 1534, Denmark was in the middle of a civil war. ${ }^{17}$ Christian III and his party came out victorious after finally conquering Copenhagen in the summer of 1536.

After his victory, Christian III successfully blamed the Catholic bishops for the miseries of the civil war and quickly imprisoned them. ${ }^{18} \mathrm{He}$, therefore, met little resistance when he called for a general assembly of the estates on October 30, 1536. Here, he announced that from now on, Catholic services were forbidden and that services were to be conducted according to Lutheran principles. The assembly of the estates approved and signed a bill, which called for a general peace and forgiveness, confiscated the bishops' properties, allowed the monks and nuns to leave the monasteries, and addressed a number of conflicts over taxation and other issues in the wake of the civil war. ${ }^{19}$ The bill gave the legal basis for a thorough but not always peaceful religious and social transformation process that had far-reaching consequences for Danish society.

Already by 1537 a new church ordinance was introduced, and the king let himself be crowned as head and protector of the church. New bishops were appointed but they were deprived of

15. Jes Fabricius Møller and Uffe Østergård, "Lutheran Orthodoxy and AntiCatholicism in Denmark 1536-2011," European Studies 31 (2013): 165-89; Martin Schwarz Lausten, "The early Reformation in Denmark and Norway 15201559," in The Scandinavian Reformation from evangelical movement to institutionalisation of reform, ed. Ole Peter Grell (Cambridge: Cambridge University Press, 1995), 12-41.

16. Lausten, "The early Reformation in Denmark and Norway 1520-1559."

17. This civil war was primarily fought between supporters and opponents of the former Danish king Christian II (reigned 1513-1523 and predecessor to Frederick I). Except for the nobility of Jutland, both parties in the civil war were already largely Protestant. Christian II who was a cousin to Christian III was disposed of the throne in 1523 by the Council of the Realm after a widespread rebellion against his harsh rule. Christian II died in captivity in Denmark in 1559.

18. Lausten, "The early Reformation in Denmark and Norway 1520-1559."

19. J. L. A. Kolderup-Rosenvinge, ed., Samling af gamle danske Love, udgivne med Indledninger og Anmoerkninger og tildeels Oversaettelser [Compilation of Old Danish Laws edited with introductions, comments and partly with translations] IV (Copenhagen: Gyldendalske Boghandlings Forlag, 1824), 157-71. 
any political power, their salaries were paid by the king, and they had no seat in the Council of the Realm. Despite widespread wishes among the clergy, the king refused to appoint an archbishop, so the church from now on had no central authority in theological matters except for the king. ${ }^{20}$ All these important changes established a particular unity in Denmark between church, state, and king under the grace of God.

This unity was reiterated at the first Reformation celebration in 1617 under King Christian IV (reigned 1588-1648). The theme of the feast was to thank God for his "graceful conduct of the land and the people" (nåderige førelse af landet og folket) (Bach-Nielsen 2015: 27). This thought, which at its core is civil religion, is found in all subsequent Reformation celebrations. ${ }^{21}$

\title{
The Reformation Jubilee Celebration in 1717
}

The Reformation jubilee celebration in 1717 is a prime example of the thinking about king, country, and God after Absolutism was introduced in 1660. It was carefully orchestrated with all the pomp and circumstances of the baroque style.

The individual events were consistently framed as a hail to the king, Frederick IV (reigned 1699-1730), and a thanksgiving to God for the liberation from the corruption of Catholicism and all the other benefits that the Reformation meant to Denmark. Speeches and musical compositions had frequent quotations from biblical texts about the deliverance of Israel from Babylon and other allegorical references to God's care for Denmark. An ode written to the main jubilee church service was in the same vein; it began with the lines:

\author{
Danske Sion! Vær nu glad \\ Ved Lutheri Morgenrøde ... ${ }^{22}$
}

In English:

Danish Zion! Now, be happy

at the first morning blush of Luther ...

20. Martin Schwarz Lausten, Luther og Danmark i 500 år [Luther and Danmark in 500 years] (Copenhagen: Gads Forlag, 2017), 44-49.

21. Christian IV also began to mark important state events in the church calendar; for example he ordained a prayer of thanksgiving for the rather mild Lubeck peace settlement in 1629, which concluded Denmark's unsuccessful engagement in the Thirty Years' War 1618-1648 (Bach-Nielsen, Fra jubelfest til kulturår, 47). It is, indeed, a civil religious idea to thank God for the results of prudent Danish diplomacy.

22. Bach-Nielsen, Fra jubelfest til kulturår, 60. 
In stanza 7, the author of the ode had let God send out a prophet, Martin Luther, who sowed a manna grain. As it sprouted in Denmark's soil, with the intervention of King Christian III, the land was cleansed of the Roman sourdough - that is Catholicism.

The distinct anti-Catholic thread through the celebration is in line with Danish legislation during the $1600 \mathrm{~s}$ and $1700 \mathrm{~s}$ which emphasized the Lutheran character of the state and was remarkably anti-Catholic on certain points. ${ }^{23}$

The Reformation celebration in Copenhagen in 1717 was organized top-down to the smallest detail, while the celebrations in the big provincial towns were locally organized by city councils and bishops in common. Especially the city of Aalborg was very active; speeches, declamations, church services, and festivals were held throughout the week, where nobility, citizens, and craftsmen celebrated the Reformation. ${ }^{24}$ All in all, in Aalborg and several other cities, there was a significant Durkheimian dimension in the otherwise Rousseauian self-celebration of the Absolute king, and this civil-religious manifestation seemed successful in gathering the people - at least in the cities.

\section{The Historical Reformation Jubilees after the Free Constitution of 1849}

The unity between church, state, and king under the grace of God was largely perpetuated after Denmark got its free constitution in $1849 .{ }^{25}$ The state church was renamed the Folk Church and about 99 percent of the population belonged to this church. ${ }^{26}$ The church continued to be administered by the state but now with the parliament as the highest authority in the church, and the reigning monarch had to be a member of the church with certain specified obligations. Legally and financially speaking, the Folk

23. Møller and Østergård, "Lutheran Orthodoxy and Anti-Catholicism in Denmark 1536-2011."

24. Bach-Nielsen, Fra jubelfest til kulturår, 70.

25. The new constitution applied to Denmark proper, not the other parts of the kingdom. Norway was ceded to Sweden after the Napoleonic wars. Regarding "the grace of God", Danish law texts begin with the words: "VI MARGRETHE DEN ANDEN, af Guds Nåde Danmarks Dronning, gør vitterligt ...” [WE MARGRETHE SECOND, Queen of Denmark by the Grace of God, make known to all men ....].

26. In 1901, 98.8 pct. of the Danish population still belonged to the Folk Church, see Liselotte J. Christensen, "Ideologier bag den politiske håndtering af religionsforholdene i Danmark 1849-1922" [Ideologies behind the political handling of the matters of religion in Denmark 1849-1922], in Fremtidens danske religionsmodel, ed. Lisbet Christoffersen et al. (Copenhagen: Anis, 2012), 199-215. 
Church was only to be seen as a governmental part of the state. ${ }^{27}$ This arrangement is still in effect today, and unlike the situation in Norway and Sweden, the church has no formal selfgovernance. ${ }^{28}$

The tradition of celebrating the Reformation at suitable anniversaries also continued, and so did the traditional thanksgivings to God for protecting the nation as well as the anti-Catholic bias. For example, when the $400^{\text {th }}$ anniversary of Luther's birth was celebrated in 1883, a prayer intended to be said in churches in Copenhagen before the reading of the biblical text ran as follows:

\begin{abstract}
Almægtige, himmelske Fader!
Vi takke dig, at Du har ladet Morten Luther fødes til et Vidne mod Pavedømmets Forførelser og sendt ham og hans Medstridere som Ørne over Aadslet! ${ }^{29}$
\end{abstract}

\title{
In English:
}

\begin{abstract}
Almighty Heavenly Father!
We thank you for letting Martin Luther be born as witness to the seductions of the Papal regime and for sending him and his co-fighters as eagles over the carrion!
\end{abstract}

As we shall see, this particular and not very ecumenical facet of the historical Danish Reformation celebrations has been abandoned today in favor of a more tolerant, even friendly attitude among most clerics in the Danish Folk Church.

\section{The Historical Differentiation of Danish Civil Religion from the Church}

Sociologist John Coleman's rather early expansion of Bellah's civil religion asked if civil religion was particular to an American setting, where it was differentiated from both the state and the church. ${ }^{30}$ Coleman claimed that in most other countries this

27. Lisbet Christoffersen, "A Long Historical Path towards Accountability, Transparency and Good Governance: On Financing Religions in Denmark," in Public Funding of Religions in Europe, ed. Francis Messner (Farnham: Ashgate, 2015), 125-47.

28. In Norway and Sweden there are elected church assemblies which decide on on all internal affairs of the church, and one of the bishops (in Norway the preses, in Sweden the archbishop of Uppsala) is chair of the assembly and may represent the viewpoints of the church. The Danish Folk Church is unique by its principle that no one in the church can speak on behalf of the church (Lausten 2016: 283).

29. Bach-Nielsen, Fra jubelfest til kulturår, 212.

30. John A. Coleman, “Civil Religion,” Sociological Analysis 31 (1970): 67-77. 
differentiation did not exist. For example, in the Nordic countries civil religion was largely expressed through the national Evangelical Lutheran churches. Coleman thereby left open the possibility that civil religion may be found in many countries, although it may not always be effectively differentiated from either the church or the state. ${ }^{31}$

In many respects the Nordic Evangelical Lutheran national churches fulfill a role of civil religion. ${ }^{32}$ This, however, does not mean that Danish civil religion today is completely contained within the framework of the Danish Folk Church. A historical differentiation process has taken place. When the Danish Evangelical Lutheran Church was a state church headed by the absolute king of Denmark, Danish civil religion and the church were inseparable. With religious liberty after the free constitution of 1849, the church did not any longer have a monopoly on expressing civil religion, and Danish civil religion gradually became differentiated from the Folk Church. ${ }^{33}$

Certain factors contributed to the development of this Danish civil religion. Until about forty years ago, the Danish population was unusually ethnic and religiously homogeneous compared with most other European countries. ${ }^{34}$ This meant that being Danish and being (Lutheran) Christian were perceived as parts of the same identity. This imagined bond between nation and Christianity was further strengthened by the influence of the pastor, poet, and church reformer N. F. S. Grundtvig (1783-1872). Grundtvig was an inescapable figure in the Danish nation-building process during the nineteenth century. ${ }^{35}$ He emphasized the key role of

31. Ibid.

32. Béla Harmati, ed., The Church and Civil Religion in the Nordic Countries of Europe (Geneva: The Lutheran World Federation, 1984); Inger Furseth, "Civil Religion in a Low Key: The Case of Norway," Acta Sociologica 37 (1994): 9-54; Susan Sundback, "Membership of Nordic 'National' Churches as a 'Civil Religious' Phenomenon," Implicit Religion 10 (2007): 262-80.

33. Margit Warburg, "Dansk civilreligion i krise og vækst" [Danish civil religion in crisis and growth], Chaos. Dansk-norsk tidsskrift for religionshistoriske studier 43 (2005): 89-108.

34. In 1974, 0.9 pct. of the Danish population came from other countries than Denmark or the other Nordic countries, and 95.2 pct of the Danish population were members of the Folk Church (Danmarks Statistik, Statistisk Årbog [Statistical Yearbook] vol. 79 (Copenhagen: Statistics Denmark 1975), 52; Danmarks Statistik, "Kirkestatistik 1974" [Church Statistics 1974], Statistiske Efterretninger 69 (4) (1977): 97-111). 1974 is the first year of the church statistics from Statistics Denmark.

35. Martin Schwarz Lausten, A Church History of Denmark (New York: Ashgate, 2016), 206-19, 238-42. 
the common man in society, and he was a leading figure in the folk high school movement with its goal of the enlightenment of the people. He was a prolific writer, and in his historicaltheological essays and compilations of Nordic mythology ran a vein of a somewhat heterodox belief in a special relationship between God and Denmark - a belief that also was expressed in his many sermons. For example, Grundtvig claimed that in God's eyes, the Danes were the "true people of the heart" (det sande hjertefolk). ${ }^{36}$

Such civil-religious ideas were sowed in Denmark's fertile soil in a critical period of nation-building, and the strength of the Grundtvigian movement sustained a widespread message to the Danes that their nation was something special to God. This message perpetuated ideas that were already salient in the Reformation celebrations in the $1600 \mathrm{~s}$ and $1700 \mathrm{~s}$, as discussed previously. It also complied with the popular national myth that God gave the Danes their national flag to assist them during a battle in Estonia in 1219. This myth, which can be traced back to the 1500 s, is still officially reiterated in public rituals, and the Danish flag is a centerpiece in many Danish civil religious events besides being waved at numerous occasions, when the Danes celebrate themselves. ${ }^{37}$

A contemporary, prominent example of a non-church, civil-religious event is the recurrent New Year's Eve celebration on the national television. Here, God is invoked as protector of Denmark twice. The first time is when the reigning Queen Margrethe II concludes her speech to the people with a brief, civil-religious intercessory prayer, "Gud bevare Danmark" (God Save Denmark). The second time is when the last minutes of the past year approaches. The passing of New Year is marked by the tolls of the heavy bell in the city hall tower in Copenhagen, not by the bells of Copenhagen Cathedral. Then a choir sings the traditional New Year hymn written by Grundtvig in which God is asked to give the country peace and a bountiful harvest. ${ }^{38}$ This is followed by the national anthem and the anthem to the monarch. This state-sponsored New Year ritual does not involve the national Evangelical Lutheran Church or any pastor at all.

Thus, Danish civil religion can be expressed both inside and outside the Folk Church, as I have demonstrated in studies of several

36. Ole Vind, Grundtvigs historiefilosofi [Grundtvig's philosophy of history] (Copenhagen: Gyldendal, 1999), 155-203, in particular 163-72, and 410.

37. Warburg, "Dannebrog: Waving in and out of Danish Civil Religion."

38. Margit Warburg, "Gudspåkaldelse i dansk civilreligion" [Invocation of God in Danish civil religion], in Gudstro i Danmark, ed. Morten Thomsen Højsgaard and Hans Raun Iversen (Copenhagen: Anis, 2005), 125-41. 
national rituals and manifestations in Denmark. ${ }^{39}$ This is also the case with the Reformation jubilee in Denmark 2017, which was launched and marketed as a broad cultural and educational event, not only as a churchly event.

\section{The Reformation Jubilee in 2017}

The celebration of the Reformation jubilee in Denmark in 2017 was, for quite a long period, in a political limbo as the government and the parliament could not decide on its official involvement and in particular on the funding. ${ }^{40}$ In 2011 , the government finally appointed a presidium for the celebration with twelve members, including one member from the Danish Folk Church. The other members came from different universities, media, and cultural institutions. The Ministry of Ecclesiastical Affairs was given the secretarial function, and Her Majesty Queen Margrethe II accepted to be patron of the Reformation jubilee.

From the beginning, the presidium did not assume for itself a role as an organiser of the many events during the Reformation jubilee. It rather aimed at encouraging bottom-up processes in the jubilee events to supplement the top-down-organized, official Reformation celebrations. This seems to have succeeded. Visiting the website of the Reformation jubilee, luther2017.dk, one is almost overwhelmed by the many events. It was made possible to register new events on the website, and in that way the presidium could exercise its coordinating function.

\section{The Official Reformation Service at Pentecost, June 4, 2017}

Denmark held its official Reformation service at Pentecost, June 4, 2017, in Haderslev Cathedral in Southern Jutland. It was shown

39. Ibid.; Margit Warburg, "Fra sørgemarch til sejrsmarch: Slaget ved Fredericia og dansk civilreligion i en globaliseringstid" [From march of mourning to march of victory: The battle of Fredericia and Danish civil religion in a time of globalisation], Chaos. Dansk-norsk tidsskrift for religionshistoriske studier 45 (2006): 129-47; Warburg, "Dannebrog: Waving in and out of Danish Civil Religion"; Margit Warburg, "Graduation in Denmark: Secular Rituals and Civil Religion," Journal of Ritual Studies 23 (2009): 31-42; Margit Warburg, "Transnational Civil Religion: The Fourth of July in Denmark," in Holy Nations and Global Identities. Civil Religion, Nationalism and Globalisation, ed. Annika Hvithamar, Brian Jacobsen, and Margit Warburg (Leiden: E.J. Brill, 2009), 271-93; Margit Warburg, "Gud bevare Danmark. Dansk civilreligion i det store og det små" [God Save Denmark. Danish civil religion, in the big and in the small]," in Civilreligion i Danmark, Ritualer, myter og steder, ed. Margit Warburg, Signe Engelbreth Larsen, and Laura Maria Schütze (Højbjerg: Univers, 2013), 7-53; Margit Warburg, "Much Ado about a Christmas Tree: A Conflict Involving Danish Civil Religion," Implicit Religion 20 (2017): 127-48.

40. Bach-Nielsen, Fra jubelfest til kulturår, 331-38. 
on national television so that all of Denmark could attend it. Haderslev is an important site of remembrance of the Reformation because the Reformation was actually introduced here already in 1526 when Christian III was the duke of this region.

The queen, the prime minister, and several other members of the government, the president of the parliament, the Danish bishops, as well as a host of invited honorary guests attended the service. The event was a clear continuation of the great festive services of the earlier anniversaries in 1617, 1717, 1817, and 1917 , and the service marked the same national unity of monarchy, church, and authority as before.

The service was, of course, a Pentecostal service in its basic structure, but with direct and indirect references to Luther, both in the selected hymns and in the sermon read by the Bishop of the Copenhagen Diocese, Peter Skov-Jakobsen. ${ }^{41}$ But unlike previous Reformation celebrations, this service was more inclusive, giving room for, among others the leaders of the Baptists and the Catholic Church in Denmark, each to declaim a prayer as part of the church prayer (the common or intervention prayer).

Inviting these two historical archenemies of the Evangelical Lutheran Church was a remarkable turn from earlier curses over the Pope and Catholicism and the religious persecutions of the Baptists in Denmark in the $1840 \mathrm{~s}^{42}$ As concluded by two Danish historians in their analysis of historical anti-Catholic currents in Denmark, the Danish Folk Church and Danish national identity no longer seem to include an openly anti-Catholic stance. ${ }^{43}$

In addition to the representatives of other Christian churches, a Danish rabbi and the national chairman of Danish Muslim organizations attended the service by invitation. This confessional inclusiveness further emphasized that the Danish Reformation service was staged in a Rousseauian process as a unifying, national religious event. One of the characteristics of civil religion is that it aims at gathering the nation across different creeds by using an inclusive frame of reference to both divinity and nation.

41. www.folkekirken.dk/aktuelt/nyheder/folkekirken-festede-for-reformationen.

42. The attendance of the Roman Catholic bishop in Denmark would probably not had been possible if Pope Francis had not paved the way by attending a joint Lutheran-Catholic Reformation service in Lund Cathedral in Scania, Sweden in 2016. This service was hosted by the head of the Church of Sweden, Archbishop Antje Jackelén who followed an urge from the Catholic Church and the Lutheran World Federation (Bjørn Tulinius, "Katolikkerne har nærmet sig protestanterne og omvendt" [Catholics have approached Protestants - and vice versa], Kristeligt Dagblad, 10 December (2015): 1, 6.).

43. Møller and Østergård, "Lutheran Orthodoxy and Anti-Catholicism in Denmark 1536-2011." 
The Evangelical Lutheran Danish Folk Church here clearly fulfilled an important role in Danish civil religion.

After the service, the prime minister held a speech in which he expressed Luther's significance to Danish society. ${ }^{44}$ He concluded by paraphrasing the first line in Grundtvig's Pentecost hymn which has become a standard hymn at Pentecost services in the Folk Church - also, of course, at this day: "I Grundtvigs salme stråler solen på os i al sin glans. Med kærlighed. Oplysning. Frihed og ansvar" (In Grundtvig's hymn the sun shines on us with all its brilliance. With love. Enlightenment. Freedom and responsibility). The last four words-love, enlightenment, freedom, and responsibility-are not present in the hymn, but were added by the prime minister, thereby formulating a Danish, civil-religious statement. My argument for this is that in Grundtvig's Pentecost hymn, the shining sun refers both to the physical sun and to Jesus; therefore, when the prime minister speaks about a sun that shines with love, he must allude to Jesus who has also given "us" (the Danes) enlightenment, freedom, and responsibility. ${ }^{45}$

The prime minister ended his speech with the following, closing words (in Danish): "Congratulations to the Folk Church. Congratulations to Denmark." This marked the unity of church and nation and the close relationship between these two pillars of the Reformation celebration.

\section{The Celebration of the Reformation Day in the Parliament}

Reformation Day is October 31 - the day that according to legend Martin Luther nailed his 95 theses on the church door of the Wittenberg Castle Church. The day was marked all over Denmark and was officially celebrated by the parliament and transmitted by television. ${ }^{46}$ The royal family, the prime minister and other members of the government, members of the parliament, and a number of invited guests from academia and the church attended the

44. The Prime Minister's speech can be downloaded from the homepage of the Office of the Prime Minister under “Taler" (speeches), http://www.stm.dk/_a_ 2371.html.

45. The first two lines in Grundtvig's Pentecost hymn read as follows: "I al sin glans nu stråler solen; livslyset over nåde-stolen" [In all its brilliance now the sun shines; the light of life over the chair of grace]. The light of life over the chair of grace is an allegory of Jesus sitting on his throne in Heaven.

46. http://mobiltv.ft.dk/video/20171/fpr/tv.4180. The day before, the Parliament also hosted a public conference over 3 hours with lectures and debates on the Reformation. The event was arranged conjointly by the Presidium of the Reformation Jubilee and the People's Univresity. https://luther2017.dk/arrangementer/arrangement/vaerd-at-vide-om-reformationen-gratis-konference-paachristiansborg/; http://mobiltv.ft.dk/video/20171/fpr/tv.4175. 
celebration. The program was composed of three speeches with musical interludes in between. In her welcome speech, the president of the parliament reflected over Luther's significance today. ${ }^{47}$ She praised his courage to stand up against the currents of the time and concluded that the Reformation has contributed much to shape Denmark as we know it today. The queen spoke about the Reformation in Denmark and was pleased by the many efforts to popularize its significance for contemporary Danish society. ${ }^{48}$ Finally, the prime minister quoted Luther's famous dictum from On the Freedom of a Christian (in Danish): "A Christian Man is the most free lord of all and subject to none; a Christian man is the most dutiful servant of all and subject to everyone."49 The prime minister then elaborated on these words as they relate to thoughts about freedom, critical thinking, and education for everybody in Denmark today. He concluded by attributing these goals to ideas that were sowed by Luther 500 years ago. ${ }^{50}$ Thus, with the authority of his office, the prime minister spoke on Luther's perception of God's relation to a Christian human and linked these words to contemporary Danish society. This is clearly an example of Rousseauian civil religion.

In a comparative perspective, the Danish Parliament's celebration of the Reformation jubilee is noteworthy. In Norway, an ecumenical church service was held in the evening in Nidarosdomen (Trondheim Cathedral). ${ }^{51}$ The Norwegian royal family and the president of the parliament participated. In Sweden the official Reformation service was held on Sunday, October 29 with participation of the royal family and the government. ${ }^{52}$ Thus, in Norway and Sweden it was the church and not the parliaments that hosted a celebration of the Reformation Day.

47. The President of the Parliament's speech can be downloaded from the homepage of the Parliament Office of the Prime Minister under "Formandens taler" (President's speeches), http://www.ft.dk/da/organisation/formanden-og-praesidiet/formandens-taler.

48. The Queen's speech can be downloaded from the homepage of the Royal House, under “Taler" (speeches), http://kongehuset.dk/taler?person_tid=31.

49. On the Freedom of a Christian is Luther's tract from 1520 which was written in an attempt to persuade Pope Leo X that Reformation theology was consistent with the Bible's teachings.

50. The Prime Minister's speech can be downloaded from the homepage of the Office of the Prime Minister under “Taler" (speeches), http://www.stm.dk/_a_ 2371.html.

51. https://tv.nrk.no/program/dmtl21300017tolk/reformasjonsgudstjeneste-inidarosdomen. Nidarosdomen is the most important cathedral in Norway, and Norwegian kings are crowned here.

52. https://www.svtplay.se/video/15722228/gudstjanst/gudstjanst-29-okt-1100 info=visa. 
In Germany, a Reformation service was held in Wittenberg Castle Church in the afternoon of October 31 with the participation of Federal President Frank-Walter Steinmeier, Federal Chancellor Angela Merkel, and the President of the Federal Parliament Wolfgang Schäuble. ${ }^{53}$ The service was followed by an official reception with invited guests from other countries in the city hall. Among other speakers, Angela Merkel spoke on tolerance: "Wir haben gelernt dass die Toleranz die Seele Europas ist" (We have learnt that tolerance is the soul of Europe) ${ }^{54}$ The event was not a nationalistic German manifestation.

\section{Local Events and Popular Initiatives}

The official Reformation service in Haderslev was preceded by a local festival arranged jointly by the diocese, the parish, and the municipality. In different tents around the cathedral people could attend speeches, lectures, performances, and music. Spectators could also buy various Luther merchandise, and the hungry could choose a special Luther hot dish or a piece of Luther layer cake produced by the local bakery. The cake was decorated with the Luther rose.

Another example of a local Reformation celebration took place on the evening of the Reformation Day, October 31, 2017, in the city of Kolding in Jutland. It began with a conversation salon about Luther's thoughts on learning and education; the salon was introduced by the theatre troupe Mungo Park. This was followed by a worship service in the city church that claimed to be "entirely in Luther's spirit." ${ }^{" 5}$ About 300 people participated. ${ }^{56}$ After the service, the participants walked together up to the illuminated Kolding Castle to the opening ceremony for a new exhibition in Christian III's Chapel. This Reformation exhibition was developed in collaboration between Kolding Gymnasium and the museum of Kolding Castle and showed, among other things, video films produced by the students of the gymnasium. ${ }^{57}$ This ended the event in which about 150 people participated, which was three times as many as expected by the planning committee. ${ }^{58}$

53. http://www.mdr.de/sachsen-anhalt/dessau/reformationstag-lutherstadtwittenberg-refjahr-100.html.

54. Ibid.

55. http://www.koldingprovsti.dk/wp-content/uploads/2016/11/LutherKatalog.pdf.

56. Interview with Pastor Martin Rønkilde, Sanct Nicolai Parish, Kolding, November10, 2017.

57. JydskeVestkysten Kolding: 2, 4, November 2, 2017.

58. Interview with Pastor Martin Rønkilde, Sanct Nicolai Parish, Kolding, November 10, 2017. 
This event combined a church service with a walk towards an important national monument, Kolding Castle, where the Reformation King Christian III died in 1559. The conversation salon placed the religious and historical-national part of the event into a modern Danish context of culture and identity. This is clearly civil religion, and it was organized locally in a combination of topdown and bottom-up processes.

Luther was known to be fond of beer. Ålborg Diocese and a local brewery stood behind the launching of a series of Reformation beers with a brochure expounding on Luther's positive relations to beer and the brewing industry: "In essence, Martin Luther believed that God had given human beings two basic forms of food in the grain, namely bread and beer." ${ }^{59}$ Besides the strong Luther beer, there was a Philipp Melanchton beer and a Katharina von Bora beer in the assortment. Katharina von Bora was Luther's wife, and the brochure emphasized that, besides her other skills and virtues, she was a talented brewer.

Viborg Diocese and another local brewery launched a competing series of Reformation beers, a Luther beer, and two other beers bearing the names of Hans Tausen and his wife Dorothea. ${ }^{60}$ Hans Tausen was a leading figure in the Danish Reformation process from around 1525 , and to associate him with the $500^{\text {th }}$ anniversary of 1517 adds another national twist to the Lutheran Reformation celebration.

These examples are but a few among a wide spectrum of hundreds of local initiatives celebrating the Reformation jubilee. ${ }^{61}$ The many initiatives and arrangements indicate that widespread, bottom-up processes had been at work, but there are no consolidated data to assess the extent of the reception among people for all the local initiatives. However, the data from the celebration of Reformation Day in Kolding indicates that it was possible for some of the local celebrations to achieve a considerable outreach.

59. Translated from http://aalborgstift.dk/udvalg/reformationsudvalg/ nyheder/reformationsol/.

60. https://viborgstift.dk/reformationsjub-2017/reformationsfejringen/3-nyereformationsoel.

61. By mid-November 2017, about 1250 events were registered on the homepage of the Presidium, luther2017.dk. In addition, there were local events that were not announced on the homepage, for example the above-mentioned event in Kolding. Some of the registered events were temporary exhibitions stretching over a period of a month or more, but the far majority (estimated about 1100) were one-day events arrranged locally. Many of these events were repetitions of performances and lectures offered nationwide by organisations and individuals. 


\section{Nationwide Dissemination}

During the days around October 31, 2017, the national broadcasting institution, Danish Radio (DR), offered a range of program dealing with Luther and the Reformation. This included historical enactments, debates, and films. The peak was a festive concert on October 31 in the DR's concert hall, which was attended by the royal family. Luther's theology and the significance of the Reformation for Danish society were interpreted in music, choir singing, and performances, and a young, popular actress recited monologues on God, Luther, and the individual human.

The other institution responsible for the nationwide dissemination was the People's University (Folkeuniversitetet) at Aarhus University. The overall idea in many of the events arranged by People's University was to "revive" Luther and his thoughts in a contemporary context. This culminated in a multitude of events in the old part of Aarhus city on Reformation Day, and I participated in as many of them as possible. For example, there were "thesis talks" where typically a researcher discussed with a non-researcher on a given topic; the discussion was guided by a facilitator who had received one to three new modern "theses" in Twitter format two weeks beforehand. This format was chosen with the argument that Twitter was the modern church door medium. ${ }^{62}$ People's University had invited a number of intellectuals to propose such theses dealing with important challenges to modern Danish society. ${ }^{63}$

One of the highlights of the Reformation Day celebrations in Aarhus was a Luther talk show where a "resurrected Luther" was played by an actor and interviewed by a well-known political interviewer from the DR. After the break and with Luther back in the grave, two university professors were summoned and crossinterviewed about some of the topics raised in the interview with Luther. The show took place at Aarhus Theatre. It was performed twice that day, and the theatre was completely full (700 seats). Before and after this event the show had been on tour to other cities in Denmark.

The evening ended with a half-hour service in the cathedral. About 350 people participated in the service. All in all, People's University estimated that about 10,000 people attended the different events in Aarhus during the week around October 31, $2017 .{ }^{64}$

62. e-mail correspondance with Anne Engedal, project leader at People's University, November 3-8, 2017.

63. Ibid.

64. Ibid. 
In a civil-religious perspective, one of the most interesting initiatives was to use the Reformation and Luther's posting of the 95 theses as a springboard for a discussion of what the Protestant heritage has meant to the Danish society and to the individual Dane today. The participants gathered in workshops to formulate 95 modern theses with visions of the future:

The idea is to give all citizens of Denmark the opportunity to contribute to a reconsideration of our society, our lives and our hope for the future through the formulation of new theses for Denmark in $2017 .{ }^{65}$

The goal was to establish ten workshops - in the end there were seventeen workshops. ${ }^{66}$ On the evening of October 31 , selected theses were projected on the facade of the theatre during a light show that also illuminated the cathedral with animated light patterns.

The basic idea of the workshops was to re-enact the beginning of the Reformation in 1517, ranging from the intellectual work of formulating modern theses to a ritual posting in public exactly on the same date as Luther posted his theses. The event thus had the dual purpose of reminding the people about Luther's 95 theses and focusing on the future of the Danish society. The framing of the workshops and adopting the thesis format of Luther's theological claims, but now dealing with Danish societal issues, characterizes the workshops as civil-religious. This project on Luther and the Reformation was not organized by the Danish Evangelical Lutheran Church, but by a secular institution, which again reflects that Danish civil religion can also be manifested outside the Folk Church.

\section{Criticism of the Celebration}

The decision to celebrate the Reformation jubilee in Denmark in 2017 has been regularly criticized in the public debate. In September 2014, the chairman of the youth section of the Liberal Party (Venstre) argued that the state should not sponsor an event that might not be of interest to all Danes as it was based on the assumption "at kirken og Gud er vores fælles fundament" (that the church and God is our common foundation). ${ }^{67}$ Several academics

65. Translated from http://luther2017.dk/arrangementer/arrangementer-paavej/national-folkeoplysning/.

66. Status report by September 2017 from People's University (unpublished). Sent by Anne Engedal, Engedal, project leader at People's University, November 8, 2017.

67. Debate between Charlotte Dyremose (MP Conservative) and Jens Husted (chairman of Venstres Ungdom), Kristeligt Dagblad, September 15, 2014, 2, 10. 
emphasized, among other things, that it should not be forgotten in the course of the celebrations that Martin Luther as the figurehead of the Reformation stood for a strong, crude anti-Semitism and religious intolerance, and that he also publicly supported the mass killing of rebel peasants. Two of the leading voices have further expounded their critique in recent books. ${ }^{68}$

Several historians and social scientists have argued that Lutheranism and the Nordic state churches have had an important significance for the later political design of the special Nordic version of the welfare state with universal services. ${ }^{69}$ The mandate of the government-appointed presidium also implicated that the Reformation has had a wider influence on Danish society and "Danish identity and consciousness," and this has been a core issue in much of the recent public debate. ${ }^{70}$ The different viewpoints enter into a major and persistent discussion about the significance of Luther and Lutheranism for the development of Danish society-a discussion that has been interpreted as a

68. Jens-André P. Herbener, Luther. Antidemokrat og statsidol [Luther. Antidemocrat and state idol] (Copenhagen: U Press, 2017); Frederik Stjernfelt, Syv myter om Martin Luther [Seven Myths about Martin Luther] (Copenhagen: Gyldendal, 2017).

69. Tim Knudsen, "Tilblivelsen af den universalistiske velfærdsstat" [The formation of the universal welfare state], in Den nordiske protestantisme og velfoerds staten, ed. Tim Knudsen (Aarhus: Aarhus Universitetsforlag, 2000), 20-64; Tim Knudsen, "De nordiske statskirker og velfærdsstaten" [The Nordic state churches and the welfare state], in 13 historier om den danske velfoerdsstat, ed. Klaus Petersen (Odense: Syddansk Universitetsforlag, 2003), 37-46; Uffe Østergaard, "Lutheranismen, danskheden og velfærdsstaten" [Lutheranism, Danishness and the welfare state], in 13 historier om den danske velfoerdsstat, ed. Klaus Petersen (Odense: Syddansk Universitetsforlag, 2003), 27-36; Lars Bo Kaspersen and Johannes Lindvall, "Why No Religious Politics? The Secularization of Poor Relief and Primary Education in Denmark and Sweden," Archives Européennes de Sociologie 49 (2008): 119-43; Sigrun Kahl, "Religion as a Cultural Force: Social Doctrines and Poor Relief Traditions," in Religion, Class Coalitions and Welfare State Regimes, ed. Kees van Kersbergen and Philip Manow (Cambridge: Cambridge University Press, 2009), 267-95; Jørn Henrik Petersen and Klaus Petersen, "Religion, kirke og velfærdsstat - er der en sammenhæng? Om velfærdsstatens opståen og udvikling" [Religion, church and welfare state - is there a connection? On the rise and development of the welfare state], Religionsvidenskabeligt Tidsskrift 54 (2009): 39-65; Niels Kærgård, Hvorfor er vi så rige og lykkelige? Om reformationen og økonomien [Why are we so rich and happy? On the Reformation and the economy] (Copenhagen: Eksistensen, 2016).

70. For leading critical viewpoints, see Jens-André Herberner in Politiken, October 30, 2016, 2, 3; Politiken, November 5, 2016, 2,5; Frederik Stjernfelt and others in Berlingske, March 25, 2017, 3, 19; and Bjørn Thomassen in Kristeligt Dagblad June 17, 2017, 1, 9. In an interview, the Minister of Ecclesiastical Affairs, Mette Bock, agreed that it is to go too far to put Luther on a piedestal and make him a kind of father figure for a lot of later developments in Danish democracy, see Information February 22, 2017, 1, 14. 
civil-religious battle for the Danish cultural identity with Luther as a central, normative figure. ${ }^{71}$ Here, I only wish to conclude that the Reformation in Denmark seems to play a mythological role for the Danish nation comparable to the different nation-building myths that permeate American society. ${ }^{72}$ This may be one of the explanations for why the politicians decided to celebrate the Reformation in 2017, despite the initially lukewarm support in the parliament.

\section{Conclusion}

The Reformation celebration in Denmark in 2017 was remarkable by its official emphasis on the national significance of the Reformation in Denmark. This stands in contrast to the parallel Reformation celebrations in other key Lutheran countries, Norway, Sweden, and Germany. The motivation for the particular Danish national, cultural, and societal staging of the Lutheran Reformation jubilee in 2017 is officially an assertion of the crucial, broad impact of the Reformation on Danish society. The older, common, anti-Catholic themes of thanksgiving to God for religious enlightenment and liberation from the papal church are gone with the participation of the Catholic bishop in the official Reformation service in Haderslev Cathedral. In this respect the Reformation jubilee in 2017 marks a discontinuity from the past celebrations. However, when I analyze the Reformation jubilees as an expression of Danish civil religion, there appears a clear continuation of a claimed positive relation between the Lutheran Reformation and the Danish nation and society. Seen from the perspective of civil religion, the celebration of the Reformation jubilee in 2017 does not rest on to what extent this claimed positive relation can find unified academic support; it rests on political and popular acceptance of old and new narratives about the Reformation in Denmark.

71. Marie Vejrup Nielsen, "Claiming Luther as a Religious Resource: Civil Religion in Conflict," Journal of Religion in Europe 4 (2011): 300-327.

72. Richard T. Hughes, Myths America Lives By (Urbana and Chicago: University of Illinois Press, 2004). 